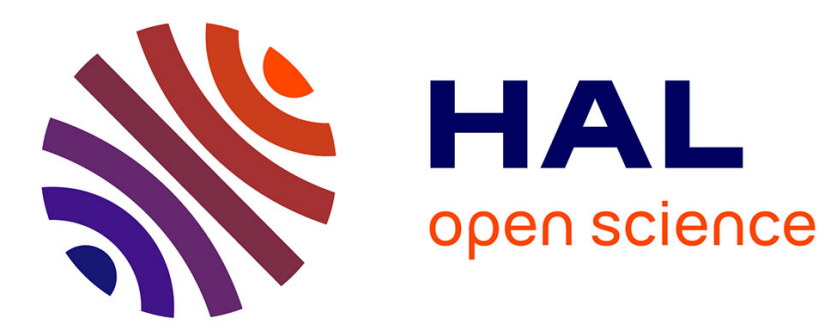

\title{
Khmer Potent Places. Pāramī and the Localisation of Buddhism and Monarchy in Cambodia
}

\author{
Anne Yvonne Guillou
}

\section{To cite this version:}

Anne Yvonne Guillou. Khmer Potent Places. Pāramī and the Localisation of Buddhism and Monarchy in Cambodia. Asia Pacific Journal of Anthropology, 2017, Potent Places in Southeast Asia, 18 (5), pp.421-443. 10.1080/14442213.2017.1375553 . hal-02528052

\section{HAL Id: hal-02528052 \\ https://hal.science/hal-02528052}

Submitted on 1 Apr 2020

HAL is a multi-disciplinary open access archive for the deposit and dissemination of scientific research documents, whether they are published or not. The documents may come from teaching and research institutions in France or abroad, or from public or private research centers.
L'archive ouverte pluridisciplinaire HAL, est destinée au dépôt et à la diffusion de documents scientifiques de niveau recherche, publiés ou non, émanant des établissements d'enseignement et de recherche français ou étrangers, des laboratoires publics ou privés. 


\title{
Anne Yvonne Guillou ${ }^{1}$
}

\section{"Khmer Potent Places. Pāramī and the Localisation of Buddhism and Monarchy in Cambodia"}

\author{
The Asia Pacific Journal of Anthropology, Special Issue "Potent Places in Southeast \\ Asia"(A.Y. Guillou and B. Brac de la Perrière, guest eds.) Vol. 18, No.5, pp. 421-443. \\ Canberra, Australian National University. ISSN (print) 1444-2213 ISSN (online) 1740-9314 \\ http://dx.doi.org/10.1080/14442213.2017.1375553
}

\begin{abstract}
Cambodia is strewn with places of national, local or, most frequently, village importance, considered as potent places, that is to say, places that are said to have agency and a positive or negative power of interaction with human beings. This paper emphasises the constituent principles of potency using case studies based on ethnographic research conducted between 2007 and 2015 in Pursat Province, western Cambodia. Beginning with the analysis of the sanctuary of a powerful land guardian spirit called Khleang Muang, the author progressively guides the reader to all the potent places that form a network which spatially tells the legend of the sixteenth century Khmer king Ang Chan who passed by Pursat coming from Angkor and settled in Lovek (south of Tonle Sap Lake). Violent death and sacrifices, rituals, spiritual energy called paramī, old buildings, monasteries, precious tableware kept in the soil, trees, stones, termite mounds ... all those constituents of the potency of the places are analysed. The author's discussion of the core of potency (pāramī and paramī) enables her to show how Buddhism and land guardian spirit cults are entangled in a single still hierarchical religious system. Finally the author analyses how potent places in Cambodia embody a process of localisation of the nation-level institution of monarchy.
\end{abstract}

Keywords: Potency; Spirits; Post-Angkorean Period; Animism; Pursat; Ang Chan

${ }^{1}$ Anne Yvonne Guillou is a researcher at the French National Center of Scientific Research (CNRS).. Her present research interests are in mass violence and reconstruction in Southeast Asia; traces of destruction, memory and social resilience in post-Khmer Rouge Cambodia; and Khmer popular religious system including the reconfiguration of the Buddhist field in today's Cambodia. Correspondence to: Anne Yvonne Guillou, IRASEC, 179 Thanon Witthayu, Lumphini, Pathum Wan, Bangkok 10330, Thailand. Email: anne.guillou@cnrs.fr 


\section{Blurred Photos. Prologue}

On 31st May 2007, the sun was setting over the monastery (vatt) of the Bodhi Tree Endowed with Merit (vatt bodh(i) mān puny ${ }^{2}$, Po Mean Bon) in Pursat Province, in the west of Cambodia. My two months of ethnographic research in the village were coming to an end. I went to say goodbye to the abbot, and told him I was coming back the following year. As I walked for the last time through the enclosure of this little-frequented vatt, new details on the ruined post-Angkorean laterite tower in its centre caught my eye. Since my last visit, only a few days previously, a number of strange, and in some cases unlikely, objects had been left there. These included two small terracotta bottles used for keeping magic potions; a cheap, brightly-painted incense jar; an earthenware statue base shaped like a yoni ${ }^{3}$ and a blue plastic dinosaur. I learnt that these objects had been presented to the ruined tower the day before by two young men from the province's main town, due to their grandmother's persistent illness'. According to the villagers who were with me, these objects may once have belonged to the monastery and this woman had been keeping them unlawfully at her home. They then gave rise to an unpleasant feeling of irritation for the grandmother, which stopped as soon as she restored the objects to the pallănk. This term, which clearly stood for the owner of the place, means, in modern Khmer, the seat of kings or the base of a statue of Buddha (there is a recent monumental statue of Buddha on top of the ruined tower). Taking out my new camera, I took detailed photos of these elements, only to find immediately that they were all blurred, however hard I tried to focus on them. My companions obviously attributed my blurred photos to the potency of the tower and the objects that had been returned to it. An offering to the Ancestor Goddess ( $y \bar{a} y$ $d e b)$, the guardian of the ruin, made only a slight improvement to the quality of my photos. The following year, my first visit was of course to Po Mean Bon. The objects had disappeared. While I was looking for signs of them, an old lay ritual specialist (acāry) replied that my particular relation (nissăy ${ }^{4}$ ) with the tower had enabled me to see the objects the year before, but that this year I was no longer able to see them. Indeed, during the following years, I saw

${ }^{2}$ I use the translitteration system of Lewitz (1969) except when the words are commonly written otherwise.

3 In Angkorean statuary, the linga, a phallic symbol representing Shiva, is embedded in a base symbolising Shiva's consort in the form of a yoni, a female sexual organ.

${ }^{4}$ Nissăy (Pali nissāya) implies a mutually dependent, thus intertwined, destiny with another person or place. 
objects disappearing and sometimes reappearing on the ruined tower, including: pieces of ancient statues made of sandstone; rejected, wrongly designed cement statues of the Buddha; small metal statues of the Buddha; as well as remains of food offerings and incense sticks.

From that day onward, I looked at the monastery and its central monument with a different eye and, throughout my research area, started looking for places which, like them, were said to have an independent capacity for action and a positive or negative power of interaction with human beings. I have observed how they come into communication with human beings, via dreams, possession, and, more indirectly, punishments or rewards. I gradually discovered that the village area where I worked was strewn with places of national, local or, most frequently, village importance, lost among rice paddies or fields, and considered as potent places, most of them related to each other.

They are not necessarily institutionalised, as Catherine Allerton (2009) has already pointed out with regard to Eastern Indonesia. Instead, local potent places are part of the daily environment of the villagers with whom I live during my research. They go there regularly at different times of day, for a walk, in passing, for a meeting (friendly discussions in small groups at slack times of day), or for activities (work at the shrine, monastery service, taking buffaloes and cows to pasture, etc.). In this way, these places are associated with the most varied personal and emotional events, such as pregnancies, land disputes, family or village quarrels, lost or found cows.

Most scholarship on religious beliefs and practices related to territory and territoriality in rural Cambodia has concerned the study of land guardian spirits, the anak tā (Porée-Maspero 1962, 1964, 1969; Ang 1986; Forest 1992; Work 20175). Anak tā are usually analysed as ancestors (in the meaning that they are the first clearers of the forest transformed into a village) although they can also be spirits of other former beings or non-human beings (or not yet human beings if the interpretation is framed in a Buddhist perspective of samsāra $\left.{ }^{6}\right)$. As Ang (1995, 219) puts it, following Mus's analysis of the 'true Asian religion, that is linked to the land'

${ }^{5}$ In her inventory of literature on spirits in Cambodia, Work (2017) provides an overview of anak tā beyond the issue of territoriality. She explores their central role in the Cambodian social landscape in relation to other spirits and Buddhism, political power, the dead and the memory of past events, and recent social movements pertaining to land eviction and working conditions in Cambodian factories.

${ }^{6}$ On the analysis of anak tā as a dead person blocked in the rebirth cycle, see Forest (1992). 
(Mus 1933, 398), 'schematically, a neak $t \bar{a}[$ anak $t \bar{a}]$ is the synthesis between two values. It is first of all the land, more precisely the territory of a particular community. In this abstract ground in which energies are divinised and looked upon through an object, particularly a megalith, the founding ancestor of the community is merged'. The anak tā is the 'master of the water and the land'.

However, as the story recounted in the prologue clearly shows, the issue of potency and its embodiment in special places goes far beyond their simple definition as abodes of anak tā. Indeed all the potent places that I have found in my research area are connected in one way or another with Buddhism or the monarchy, although most of the time anak tā or other spirits like brāy are also involved, as well as natural elements like big old trees, termite mounds and animals. These places are as varied as a former sixteenth century military leader's shrine, a ruined tower built by a post-Angkorean king, monasteries whose legends speak of the battles during the same period between the Siamese and Khmer armies and involve the royalty. The question is as follows: how all those elements make sense together and are integrated in a single perception of the potency of the place, mostly through practices and narratives. My purpose in this article is thus to draw on detailed ethnographic accounts of the social practices and perceptions of these sites in order to emphasise the complex constituent principles of potency and draw up an interpretative model of this energy in Cambodia. This will lead me to discuss in the conclusion the integration of land guardian spirit cults and Buddhism into a hierarchical single religious system on the one hand and the process of localisation of a nation-level institution, monarchy, on the other.

The examination of the core of the potency is fundamental to this discussion. Indeed these potent places are said to be full of an energy called pāramī/paramī. They are less frequently and more loosely branded 'strong places' (kanlaen khlämin) and 'places which have influence' (kanlaè mān iddibal). Pāramī (Sanskrit pāramitā) is well known to scholars of Asia. It refers, in the Mahayana, to the six Virtues cultivated by a Boddhisattva to become a Buddha. In Theravadin countries like Thailand and Cambodia, the monarchy has assumed the role of protector of Buddhism. In the Thai language specifically, the meaning of pāramī has evolved from the Buddhist virtue to the potency of the virtuous kings (Sirindhorn 2006) through the assimilation of the king with a boddhisatta - particularly Vessantara - endowed with all his/her qualities. Kings' good deeds as rulers increase their pāramī which in turn enables them to perform miraculous acts as well as to provide their subjects with prosperity and protection (Jori 2002, 52-53). This notion culminated during the early Bangkok era in the eighteenth century and is still very much present in the monarchical political and economic 
system built by the late king Bhumidol (Ünaldi 2014). Pāramī is extended to ordinary Thai people outside the monarchical elite circle at all levels of leadership, in reference to their personal selflessness and willingness to help their clients without relying on their power. This spiritual capital can in turn be converted into political power (Persons 2008). ${ }^{7}$

Pāramī has a long and partially similar history in Cambodia where the kings have also been endowed with the virtues and subsequent aura and potency stemming from their good deeds as Buddhist rulers. However, it has evolved into two separate but connected notions, those of pāramī and paramī; the first understood in its etymological meaning of Buddhist virtues extended to kings and royalty while the second implies a broader and less specific energy circulating in potent places, objects and people. ${ }^{8}$ Various authors (Ang 1986; Forest 1992; Bizot 1994) have put forward theories about the semantic evolution of pāramī, from 'Buddhist perfections' to the power of certain entities in the Khmer religious pantheon. However, paramī has not been fully documented in Cambodia in the specific configuration of potent places, although it is mentioned obliquely in some works (Ang 1986; Bertrand 2001; Davis 2016; Work 2017).

I intend to explore here the relation between these separate but complementary notions of pāramī (Buddhist and royal potency) and paramī (circulating energy in certain places, natural elements, artefacts and spirits). I will use case studies based on ethnographic research conducted between 2007 and 2015 (more than a year in total) in Bakan district, Pursat Province. The area includes the shrine of a land guardian spirit (anaktā) named Khleang Muang. This is the archetypal potent place $^{9}$, even though it presents some original features. It is also at the centre of a set of sites, which are connected with each other. I will describe them later, since each of them is an extra facet of the potency that is concerned here.

${ }^{7}$ The type of individual who can convert moral capital into social and/or political capital is referred to in Khmer language as anak mān pūny (person [who] has [Buddhist] merits).

${ }^{8}$ For the purpose of clarity, I will use the spelling parami in this specific meaning. This is the usual way people refer to potency of place in my research area. However, some of them pronounce it according to the spelling pāramī and others acknowledge both pronunciations. Bizot (1994, 116) has already mentioned this difference. Spelled paramī and pronounced accordingly, the word, he writes, means 'force', 'potency', 'sacred energy' emanating from a ritual artefact in its broadest meaning, particularly from the gods assisting Buddhism. Bertrand (2000) finds the same difference in his study of the spirits called paramī.

${ }^{9}$ Complementary research in the western province of Battambang (western Cambodia) around the legendary character of Grandfather Iron Stick and in the south-eastern province of Prey Veng around the land guardian spirit Me Sa at Ba Phnom come to similar conclusions. 


\section{The Shrine of Khleang Muang: Political Power, Chthonian Potency}

Ten kilometres north-west of the town of Pursat is the shrine of Grandfather Khleang Muang, one of the most famous land guardian spirits (anak tā) in Cambodia. This figure combines in a single being a mythical-historical sixteenth century military leader, and a guardian spirit whose field of action extends to the entire west of Tonle Sap Lake. The site remained a modest shrine to a guardian spirit until the Khmer Rouge period (1975-79), when it grew in importance thanks to the action of the charismatic director of Pursat Province's Culture department. ${ }^{10}$ It is now developing quickly, and is frequented both by government dignitaries (though not all of them), and by travellers, rich and poor, who take the main road from Phnom Penh to Battambang; the villagers also keep up daily contact with it, though in a different way, as I will explain later. The magnificent shrine is surrounded by an extensive garden that is constantly being improved. It is decorated with many ornamental statues - from an enormous cement statue of a gorilla to the costly sandstone equestrian statues of Khleang Muang's four sons. Newly-weds like to have their photos taken on the little 'bridge of happiness' over the pool or in front of the statues, covered in small squares of mirror-glass, that represent the twelve animals of the Khmer horoscope.

The story of Khleang Muang is known to all Khmers today. He shares, with other anak $t \bar{a}$ (though not all), the peculiarity of being a former human being. This former military chief commanded the troops of the post-Angkorean king Ang Chan (dynastic name Paramarājā II, 1516/17-1566) against the Siamese army. Khleang Muang is venerated nationwide as a national hero, at least since independence (1953). According to the legends, backed up by the royal chronicles (Khin 1988, 126-129; Aen 2000), he committed suicide in order to go to the kingdom of the dead and raise a ghost army to put to flight the Siamese army that had come to support the Khmer usurper Kan (Leclère 1910). Khleang Muang thus became a symbol of patriotism and sacrifice in the service of the nation. School textbooks and radio programmes

${ }^{10}$ Originating from another province, he was appointed to the Pursat Province Culture department right after the Pol Pot regime in 1980. A complex character, he felt progressively closer to Khleang Muang until he replaced de facto the former local ritual servant. He then launched an ambitious building programme that aimed at attracting visitors of higher social background, likely to make more substantial donations, beyond the village circle. 
are devoted to him, and soldiers and politicians of all ranks and all persuasions today claim to have been inspired by him and come to venerate him. ${ }^{11}$

The power of Khleang Muang and his shrine is construed as a result of several different elements which are elaborated below.

INSERT IMAGE 1 - Khleang Muang's shrine. Pursat. 2008. Author’s picture

\section{A National Hero}

I will first observe Khleang Muang in his role as 'strong man', a former living person and a protective ancestral figure. This side is increasingly emphasised today by the Culture department, which manages the site. ${ }^{12}$ Before the Khmer Rouge regime), Khleang Muang was only represented in the form of a termite mound, the usual sign of the presence of a chthonian spirit. Then his anthropomorphism became increasingly realistic. Until 2010, this consisted of one, then two Pursat stone statues, painted with a greenish varnish in the local style. He was shown in court clothing, with a severe moustache and an authoritarian eye, his finger pointed at the ditch where he is supposed to have killed himself by throwing himself onto pointed spears. At his side, smaller and frailer, was his wife, Khān Khīev. The portrayal was of Thai inspiration. ${ }^{13}$ The clumsy execution of the statue, poorly proportioned, with legs like tree trunks and a fixed stare in eyes whose irises were painted black, all showed a portrayal of still uncertain humanity. In 2010 the Culture department had a new statue made, projecting a very different message about Khleang Muang's identity: his features are so well defined that a person must have been used as a model. Khleang Muang is shown seated, in a noble but very human pose, on a throne, under a parasol showing his rank. His wife (or the feminine part of

11 The Prime Minister has never been there, according to rumour, since he has fostered since the early 2000s the idea that he is the reincarnation of Kan (Norén-Nilsson 2013), King Ang Chan's enemy, and thus also Khleang Muang's.

${ }^{12}$ Since the end of the Pol Pot regime, Khleang Muang's cult has progressively become the subject of an undercover dispute concerning the financial and ritual management of the shrine. The protagonists are the Culture department, in the person of its director (now retired but still active) and people from the surrounding villages.

13 The statue also closely resembles that of Chao Anou, the last king of Vientiane, whose statue faces the Mekong in this city. Thanks to both Marc Mouscadet and Christian Taillard for information on this subject. 
his identity ${ }^{14}$ ) has disappeared. It is therefore the 'presence' of a general of the royal army, which gives this place its strength.

This is a place built like a place of power, which is one of the forms of a potent place. The place of power is the place where political power is shown or expressed, whether that of the king or of his ally, the army. ${ }^{15}$ This recent desire to give the shrine an identity as a place of power is also manifest in many other ways. For example, at the annual homage ceremony to the spirit-national hero, which takes place in the lunar-solar month of bisakh (April-May), the space occupied by the provincial authorities, especially the province's governor, has greatly increased at the expense of that of the peasant community. The director of the Culture department who has made the management of the site his personal mission does not hide his desire to attract influential devotees and elevate the shrine to the rank of a major tourist site of national, or even international importance - a dream which has little chance of coming true since Pursat Province has few visitor attractions.

Construction work (buildings, statues, monuments) is one of the most important elements in building up the reputation of a powerful Cambodian man or woman, such as the former director of the Culture department.

\section{A Land Guardian Spirit}

The peasants living close to the shrine are more attached to Khleang Muang's identity as a powerful land guardian spirit (anak tā). For them, the potency emanating from this place is that of the guardian spirit, merging with that of the soil (Mus 1933). This energy sometimes presents personified features (like Khleang Muang), but, in other places, merges with the soil, hence the absence of representation (the anaktâa's house is empty) or representation in the form of a stone or a termite mound.

${ }^{14}$ If we consider Khleang Muang as a guardian spirit, anak tā sometimes have a double of the opposite sex, which is accorded varying degrees of importance. I have observed this fact in the villages where I have worked. Ang $(1986,202)$ also mentions it.

${ }^{15}$ The former commander in chief of the royal army Ke Kim Yan (until 2009), and Nhek Bun Chhay, the (royalist) second in command of the armed forces until the 1997 coup, are reputed to be fervent devotees of Khleang Muang. I have myself observed a meeting held by Nhek Bun Chhay at Khleang Muang's shrine. The spirit is said to have saved Nhek Bun Chhay's life when he fled in 1997 by making him invisible. 
The very name Khleang Muang (Ghlāṃn Mīoeñ) indicates a strong link to the soil. This name is a composite of various influences. In the Thai language, it means 'middle of the country or territory'. ${ }^{16}$ Mīoen is undeniably a Thai word. As for ghlämn், it means 'warehouse, depot, treasury, bank' in the Khmer language but it does not make sense here, whereas the slightly different word khlāmin means 'strong'. ${ }^{17}$ Ghlāmin Mīoen would then take on the meaning of 'the strong (man) of the country or the region'. The double-entry etymology (national hero and guardian spirit) therefore contains the same ambiguity as the entity itself. The dimension of the 'strong man of the country' is also emphasised by the title of Suorgā lok that I have heard given to Khleang Muang by a villager. This title was held by the 'prince' ruling the region (stec trāñ) of western Cambodia in the post-Angkorean period (Leclère 1910, 12), suggesting that Khleang Muang was the invisible double of the human ruler.

The idea of the centre of the territory ${ }^{18}$ is reminiscent of that of 'navel of the village' (phcit bhümi), which in circular Khmer villages in Siem Reap Province designates the central post, phallic in shape, symbolising the village as a whole ${ }^{19}$ in fertility rites (Din, undated). I cannot tell at what date these three concepts - the sacred post, the national hero and the anak $t \bar{a}$-started to overlap, but the texts of the royal chronicles, written in the nineteenth and twentieth centuries, already mention that Tā (Grandfather) Muang, after his death, became the anak tā Khleang Muang. These documents clearly indicate that Ta Muang's aim was to change himself into a land guardian spirit capable of helping the living (Khin 1988, 163). His wife is also known as Khīev (blue), a colour associated with the brāy, spirits of violent death (Ang, pers. comm.).

The places where anak tā dwell are never mere residences since they all share the same ontology as the anak tā. Khleang Muang's 'aura' ${ }^{20}$ thus extends consubstantially to his domain

\footnotetext{
16 Thanks to Ang Choulean and Michel Antelme for linguistic clarification.

${ }^{17}$ Olivier de Bernon and Michel Antelme's hypotheses (personal communications).

${ }^{18}$ There are several other Khleang Muang. Porée-Maspero $(1962,10)$ reports that in Kampot province,
} Khleang Muang dwells in the Hill of the Door (bhnam dvā). Ashley Thompson (2008) has observed in the monastery of Vāṃn cās' in Udong a ritual of calling Khleang Muang. According to the royal chronicles (Khin 1988, 72), a khleang moeung (sacred post) was established in Phnom Penh during the founding of the capital by Ponhea Yat.

${ }^{19}$ Among the potent places associated with Khleang Muang's shrine, the monastery of Bakan was also referred to as the « navel» of the country by several of my interlocutors.

20 «Aura » is one of the accepted meanings of the term pārami. 
and shows itself in different ways: tree branches that move alone and refuse to be cut; lights at night; the presence of a tiger before the Pol Pot regime; a new shoot growing from a dead tree; dreams in which Khleang Muang communicates his messages; spontaneous possession, sometimes many miles from the shrine. ${ }^{21}$ His potency is strengthened by the presence of certain large trees ${ }^{22}$ reputed to possess paramī. This guardian spirit is a haughty 'master of earth and water', like most of his fellows. He is neither good nor evil but keeps a jealous watch on his property, each element of which is part of himself. He does not tolerate disrespectful behaviour on his land. There are many stories of punishments meted out to those who dare take wood or engage in amorous effusions in the shrine's area without asking his permission.

The other 'masters of water and earth', the Khmers Rouges ${ }^{23}$, were not able to get the better of Khleang Muang. It is said that the revolutionary soldiers who destroyed his shrine to dig an irrigation canal (a symbolic act representing the triumph of materialism over 'superstition') paid for it with their lives; afflicted each in turn by deadly diseases or dying in accidents.

Villagers and pilgrims come to ask the guardian spirit for help and protection in a relationship that is a kind of contract. The person who asks a favour of Khleang Muang promises to make a certain type of offering if his/her wish is granted. Passing several times a day through this shrine during my field research, I saw families in their Sunday best every day, organising small private ceremonies for ten to thirty people, known as la pamnan', during which the spirit and his wife are invoked and the offering 'sent' to them. However, the prayers are not only addressed to Khleang Muang and his wife, but to the place as a whole, which the pilgrims stud with votive incense sticks. Anyone who forgets their promise will be severely punished by Khleang Muang. The more powerful the 'master of earth and water' is, the harsher the punishment for the neglectful devotee.

${ }^{21}$ Teri Yamada (2004) has observed a cult of Khleang Muang in Long Beach, California.

${ }^{22}$ Certain trees are said to be potent trees. Some of them shelter land spirits and 'absorb' their potency. For example Bodhi trees (Ficus religiosa L.), tamarind trees, samron trees (Angiosperms, class Dicotyledons, family Sterculiaceae, trees of second growth forests) and sṇuol trees (Dalbergia nigrescens Kurz, trees of dense forests) (Martin 1971, 76, 101) are perceived as potent. I have often heard stories of places that had lost their potency because their trees had been cut down.

${ }^{23}$ Pol Pot and his cenotaph have become the objects of a cult in many ways similar to that of an anak tā. He is called 'master of the water and the land' in northern Cambodia (Guillou 2016). Locard (1996, 34 cited in Work 2017) recorded that the Khmers Rouges claimed to be 'the masters of the water and of the land'. 
Living among the local population, including those working at the shrine as caretakers, workmen or musicians, enabled me to pinpoint the elements making up the potency (param $\vec{\imath}$ ). Large, centuries-old trees, the abundance and quality of offerings, especially during the annual homage ceremony, the quality of the congregation present on these days - including the soldiers firing several salvoes in the spirit's honour-all strengthen the potency of the place in a kind of circulating energy. Political power, which is normally also an ingredient of potency, tends here, as I have already shown, to break away from the 'potent place' complex. It is too early to say whether this is a temporary, accidental state of affairs ${ }^{24}$ or whether it is the sign of a more general development in Cambodia, where the phenomenon of constructing a locality involved in the erection of potent places is changing scale, abandoning the traditional local level (sruk) to become provincial or national through such activities as tourism ${ }^{25}$ and travel throughout the country enabled by road building since the 2000s; profound modification of land ownership with the purchase of land by investors from outside the surrounding villages; mass emigration of young villagers to Thailand.

\section{Bloody Offerings and Violent Death}

I have shown that the potency of Khleang Muang's shrine refers to several creative principles: guardian spirit and ancestrality ${ }^{26}$ on the one hand and political power on the other. Another element may be added to this, that of violent death (in this case, voluntary death). From the villagers' point of view, this is a fundamental element of the potency of Khleang Muang and his shrine. He committed suicide by impaling himself on pointed spears, stuck into the bottom of a ditch where, according to legend, his shrine was built. Two statues show him pointing his finger at the place (called 'tomb' in Khmer) where he is said to have thrown himself. According to certain oral versions of the story, he was accompanied by his wife and children. This suicide presents different values with relation to the potent place. The first level

${ }^{24}$ The director of the Pursat Province Culture department, although officially retired, is still in charge of the shrine. He is now elderly and his succession may give rise to a change in the evolution of the management of the shrine.

${ }^{25}$ Khleang Muang has featured in tourist guides since the early 2000s, even though, to date (2016), he only attracts a handful of foreign tourists per year.

${ }^{26}$ The 'ancestor' in the sense of the founding member of a family line or social group is not, in Cambodia, the subject of a cult outside that of family ancestors ( $j \bar{\imath} d \bar{u} n$ ji $t \bar{a})$, especially parents and grandparents, who have their own altar in the house. Ancestrality in this case is therefore the sense of an earlier presence on the land. 
is that of violent or premature death. Dead persons have difficulty detaching themselves from this world; They wander among the living and their intentions are not always benevolent. They continue to live in the place of their tragic death and imbues it with their presence. But, beyond the appearance of a ghost, violent death gives off an energy, which can spread to the place where it occurred. The metaphor of absorption used by Judith Bovensiepen $(2009,325)$ for East Timor is also valid for Cambodia, 'places have absorbed past experiences and deaths, turning the land into a source of danger' ${ }^{27}$ In Cambodia, what is absorbed is, in my opinion, vital energy that has not been consumed on account of a premature death. ${ }^{28}$ It is also noticeable that this site, in Khmer portrayal, is not only Khleang Muang's tomb but also the scene of bloody battles where hundreds of soldiers lost their lives, as a picture hanging in the shrine reminds the visitors.

The second level is that of the bloody offering, a human one, what is more. I will not, of course, describe here in detail the ancient ceremonies, elements of which would be difficult to find today. I will simply note that annual homage ceremonies were organised for important guardian spirits in the post-Angkorean period. They were perceived as the invisible representatives of the five 'regional kings' of Cambodia (stec trāñ $)^{29}$. The homage rituals included bloody human sacrifices (until 1877 in Ba Phnom), only later comprising sacrifices of buffalo, then of pigs, and, in the 1940s, offerings of meat, consisting of pork bought at the market (Chandler 1972). Even today, in Pursat, the sacrifice of buffalo during the annual homage ceremony is symbolised by a pair of horns presented among the offerings. Khleang Muang's voluntary death may therefore also symbolise such a human sacrifice. These bloody offerings, which lasted several centuries after the introduction of Theravada Buddhism to Cambodia in the fourteenth century, contributed in any case to the potency of the place and, in the villagers' minds, Khleang Muang’s sacrifice continues to give the place its strength. ${ }^{30}$

27 The potency of place is shaped by the idea of danger in many Austronesian societies (Bovensiepen, 2009, in the context of East Timor; Rappaport in this volume in Flores). In Cambodia, potent places are more likely to be places where one would be advised to be careful.

28 The mass graves of victims executed by the Khmers Rouges ['s' necessary? YES SEE MY COMMENT ABOUT THIS IN MY EMAIL] are also particular places giving off a similar type of force. The promise of life, in this case, was broken off sharply (Guillou 2014).

${ }^{29}$ Pursat had its own stec trā̃n.

${ }^{30}$ Guardians of cities or temples are spirits of persons who died violent death in Cambodia and beyond.The Thai royal chronicles mention human sacrifices taking place in the protection of cities such as Bangkok, Vientiane and Luang Prabang by a phi müang or land guardian spirit. Bernard Formoso $(1998,14)$ tells 
Khleang Muang's shrine is thus highly charged with meanings and practices. It is characteristic of Khmer potent places to be the recipients of an accumulation of symbols, practices and objects - a kind of reservoir of energy which must be filled, and which can be drawn from. This type of site has another characteristic, which is to be part of a network of places. In my research area, this mesh, centred on Khleang Muang, finds its meaning in the turbulent and violent history of the post-Angkorean kings forced to leave Angkor under Siamese pressure. These episodes of war and flight have left numerous marks in the region. The Siamese attacks on Angkor in 1432 forced the Khmer kings to retreat south of Tonle Sap Lake (whereas the Angkorean capitals were north of this great lake). This march southwards is strewn with the ruins of laterite shrines, stupas, statues and monasteries dating from the early days of Theravada Buddhism, whose history still mostly needs to be established. In the villagers' minds (their fame is rarely more than local), these ancient ruins have often become powerful places and objects since they are associated with royalty, one of the important elements of paramī.

\section{Potent Places in Action: A Territorial Network}

Around Khleang Muang's shrine, within a radius of ten kilometres towards the forested hills of the Cardamoms to the west, the landscapes and place names have been marked by the sixteenth century battles between the Khmer and Siamese armies (see image 2): the monastery of the Bodhi Tree Endowed with Merit (PMB); the King's monastery a few minutes away by moped; and a half-hour journey by the same means of transport, the monastery of Bakan. Of all these places recounting the exploits of King Ang Chan and the general of his army, only the hamlets named Citadel of Victory and Siamese Camp - a sunken, overgrown path - seem completely 'harmless' $\left(s \bar{a} p^{31}\right)$. All the other places contain a greater or smaller quantity of components of potency, and are ritually maintained as such.

INSERT IMAGE 2 - Potent places associated with Khleang Muang’s legend

\section{The Shrine of Brāh jī / Tà jī: A Land Guardian Spirit Disguised in a Buddhist Altar}

the story of the land guardian spirit Cao Com, 'Lord of the Summit', similar to that of Khhleang Muang. He also died voluntarily by impalement—-but on the tusks of an elephant.

${ }^{31}$ Sāp means « bland » or « devoid of power ». 
Five hundred metres or so from Khleang Muang, there is an altar of Buddhist construction placed on a hillock, rather unusual in the present-day religious landscape. ${ }^{32}$ According to some people, this actually contains the gru (personal protective spirit) of Khleang Muang. Under the patronage of a local civil servant, the site is given progressively more Buddhist features from year to year. Since 2007, the trees in the grove, which frightened schoolchildren returning home after nightfall and fired their imagination, have been cut down. The wooden shelter has been rebuilt in cement on a tiled floor. It contains a new statue of Buddha-while keeping the remains, full of paramī, of the old one destroyed by Pol Pot's soldiers. No statue of Buddha, regardless of its condition, is ever destroyed or thrown away. It is preserved in a potent place, often a tree or a Buddhist altar.

However, the multiple names ${ }^{33}$ given to this place by various villagers show clearly that it is not simply a Buddhist altar. Ming Mom, who lives just behind the altar and often comes there to rest after selling noodles in the morning on the terrace of Khleang Muang's shrine, points to the 'grandfather's children' (kūn lok $t \bar{a})$, centipedes and the termite mounds which show the living strength of this place. After the annual homage to Khleang Muang during the month of bisākh (May-June), the villagers organise in this place a ritual to ask for rain, a request usually addressed to guardian spirits of a certain importance.

INSERT IMAGE 3 - Shrine of Brāh jī. Ming San asks Grandfather Chi's help in a land grabbing case. Pursat. 2007. Author's picture.

This site is part of a connected set of potent places, which act on the individuals with whom they are in harmony. This is what I was told by Ming San, a trader on the market in Pursat town ${ }^{34}$, ten kilometres away, whom I met one day at this site:

${ }^{32}$ Buddhist shrines consecrated by ritual boundary markers ( $\operatorname{sim} \bar{a}$ ) are usually found inside the enclosures of monasteries (vatt) and not in isolated positions like this one.

${ }^{33}$ Brāh jă (main Buddhist statue in a monastery) brāh ang jī or bjū (idem), vatt yāy jī (monastery for pious women respecting the ten precepts), lok tā $j \bar{\imath}$ (Grandfather Chi) tā jī (idem) or pallăṅk brāh (Buddha's place of residence).

34 'Market people', especially from important markets like those in the provinces' main towns, form a different social group from peasants. 
'Before, I used to go to the King's monastery [another potent place associated with Khleang Muang, see below]. Passing by here on my motor-bike, I noticed the roof [of the altar] and I stopped because I thought it was not right to pass by without stopping. The next day, I sold more lottery tickets than usual. The day after, I sold even more. It was an incredible month. I earned 2,000 dollars. Then the rainy season started, and I was very busy. I didn't take the time to come and pay homage to Grandfather Jī. In the space of a few weeks, I lost 20,000 dollars. I came back to honour Grandfather J̄̄, and my business picked up again' (conversation with author, May 23, 2007).

Ming San also came to Grandfather Jī about a case of land theft, and, thanks to him, won the case that the corrupt justice of humans had not allowed her to win, she said, rejoicing in the misfortunes that befell the guilty person and his family. This is another common attribute of anak tā.

The second potent place visited thus shows perfectly how the constituent elements of potency can be added together without any sense of contradiction (present Buddhist appearance, land guardian spirit, presence of natural elements such as a grove, a hillock, trees, ancient objects like a stone mortar and ritual boundary markers). It also enlightens how, on the other hand, individuals move from one place to the other in the mythical-historical geography of potent places.

\section{The Ruined Tower of the Monastery of the Bodhi Tree Endowed with Merit, and King}

\section{Ang Chan's Epic}

Five hundred metres further along the red earth road towards the west stands one of the important places on this imaginary map, the monastery of the Bodhi Tree Endowed with Merit (PMB). Unlike Khleang Muang's shrine, this monastery is rarely visited and it feels sleepy. Work on the rebuilding of the main shrine and the monks' refectory started years ago but shows no sign of completion. Also, few monks live here. This shows clearly that a potent place is not always a place of pilgrimage or an important centre. The monastery is directed by a very old monk who has not been able to attract donations or make a reputation as a healer outside the local area. By contrast, the King's monastery has shaken off its torpor, reinvigorated by the personal powers of its new abbot. The head of PMB monastery is aware of this situation, and in one of our many conversations since 2007, he has analysed it in terms of life cycles. 'This monastery will not develop until the Bodhi Tree which has grown [by magic] on the ruined 
tower $^{35}$ [a major element of the monastery's paramī] is sixteen years old. Like a girl, it will then be completely nubile. That will be in two years. Until then, even if I received donations to the monastery, they would not do any good, the monastery will remain in the same condition' (conversation with author, February 21, 2014).

INSERT IMAGE 4 - The potent old tower in PMB monastery. Pursat. 2008. Author's picture.

The ruins of a post-Angkorean laterite tower do indeed stand in the middle of the monastery. Today it is known to the villagers as the pallănk (a monumental statue of Buddha has been built on it since the end of the Khmer Rouge regime). There is no need to go into detail; everybody knows that the 'pallănik' is this ruined tower. All my interlocutors link the potency (param $\vec{\imath}$ ) of the pallănik to King Ang Chan's legend, even though the names, the family ties between protagonists and the details of the legend vary from one account to the other. The monastery of PMB, where the Khmer troops camped in the sixteenth century, is also a royal burial site. Ang Chan's first cousin, Ponhea Ong, the very same who, loyal to the king of Siam, was killed by the Khmer army, was cremated here and his funeral urn placed in a stupa, then a monastery was built (Khin 1988, 157). The royal chronicles evoke the memory of a Bodhi tree, long dead, which miraculously grew here while the Khmer royal army was bivouacked before engaging in battle. King Ang Chan immediately interpreted this strange occurrence as a presage: 'the Bodhi tree (...) is us' (153), meaning that the royal line ousted by the usurper Kan would come to life again, just like the tree.

The sacred/royal ${ }^{36}$ component of the potency of this place supposedly still exists today, for example, in the form of a particular attraction of the PMB monastery for those of royal blood. In 2008, I was told that a man from the royal branch of the Norodoms, who was passing on the main road five kilometres away, was attracted by his 'dependent destiny' (mān nissăy) with the pallănk and asked permission to take away a small earthenware bottle, reputedly ancient and potent, which had been left there in the circumstances that I described in the prologue.

35 The superior has brought up to date the legend of the monastery's founding, when a banyan tree grew by magic during the reign of King Ang Chan. The king interpreted it as a sign of his future victory over the Siamese army as I will show below.

${ }^{36}$ In Khmer the particle 'brāḥ' means both 'royal' and 'sacred'. 
The pallănk (the base of the tower), to a far greater extent than the altar Brạh $j \bar{l}$, described earlier, has its own personality and wishes. These are expressed mainly in its capacity to act as a kind of extensive treasure chest, opening and closing as the mood takes it. The royal chronicles mention, as precious objects placed in this monument, two gold statues of the meditating Buddha, allegedly cast on the orders of King Ang Chan. But local stories, in the widespread tradition of treasures buried and then restored to people of merit ${ }^{37}$, evoke the abundance 'of ancient things, gold, silver, sapphires, all the kings' possessions ${ }^{38}$ preserved in the pallănk of PMB, according to the words of the lay ritual specialists of the monastery. It is therefore a 'place of great value', they conclude - the 'value' of these precious objects forming part of the potency of the place. The pallănk containing these treasures acts as a jealous owner. There is a story about it, commonly told in Cambodia, concerning precious dishes which were once borrowed by villagers for their ceremonies: 'In the past, people asked the monastery's pallănik, or monastery's paramī [paramī in this case designates the protective spirit] to open, to lend these dishes. They brought them back after using them. But people became bad, and lost their honesty, so the pallằnk closed up again and will no longer lend anything'. Thanks to its paramī, this pallănk has become a keeper of ancient royal treasures, and anyone attempting to steal the precious objects buried inside it would be punished. This is what happened to the Khmer Rouge soldiers, an old woman living nearby told me: when they tried to remove the stones from the laterite base, they died before finishing the work.

The royal and Buddhist nature of this place, the scene of kings' and princes' ancient battles and burial place of Prince Ponhea Ong (giving off the energy of violent deaths), the presence of a buried treasure held in a ruin endowed with agency, all contribute to the potency of a place and attract local devotees during Buddhist annual ceremonies.

INSERT IMAGE 5 - Incorrectly moulded cement statues kept near the old tower, PMB monastery. Pursat. 2008. Author's picture.

${ }^{37}$ See Anne Y Guillou (2013) concerning the idea of the earth « absorbing and giving back » these buried treasures.

${ }^{38}$ My interlocutors in PMB mentioned: glasses; flasks; plates especially the pañacarañg carved type with five alternate colours used for the king's meals; containers (phdil) and bowls (thass) used for the presentation of offerings. 


\section{The King's Monastery and the Aura of its abbot}

Three kilometres further down the road, one reaches the King's monastery (vatt hluori), from which a recently built stairway goes down to the beautiful, peaceful Pursat river. Although the royal chronicles do not specifically mention that this temple was founded by King Ang Chan, the present-day inhabitants make the link very clearly. Thus, for example, the funeral monument, restored by Cambodians from the United States, is said to contain the remains of one of Ang Chan's children, according to one of the lay ritual specialists. On this foundation stone, there are other clues to the temple's link to Khleang Muang's shrine: a poorly made cement statue of him has been erected under a small shelter; the monastery's racing canoe bears the name of 'potency and victory of Khleang Muang' and, especially, one of the monastery's main lay ritual specialists is none other than the ritual servant (me smịn) of Khleang Muang, responsible for his cult and claiming direct descent from him via the paternal line. ${ }^{39} / /$

The potency of a place such as this requires regular 'upkeep', which, in the case of a monastery, is principally the responsibility of the abbot However, during my first visit in 2007, the monastery had lost its strength because nobody had possessed the necessary aura since the death of the last abbot. The monastery was idling, living on the memory of an abbot from the time of the French protectorate, who was able to deflect bullets without them piercing his flesh. This is a recurrent theme in Cambodia, with invincibility often attributed to tattoos, though in the present case, this was due to the personal aura of the head of the monastery. In 2008, the King's monastery found a superior whose magical gifts and former career in the army enabled him to attract the attention of several rich benefactors. In the space of a few years, the potency of the place was restored through the construction of many new buildings, each more magnificent than the last. Statues of the Buddha in rare types of wood from the Cardamom forest ${ }^{40}$ are particularly numerous, reminding the visitors that the main patron of this place is a powerful businessman who made his fortune in the wood trade, Try Pheap.

\section{The Travelling Bodhi Tree of Bakan Monastery and the Peregrinations of the Kings}

\footnotetext{
${ }^{39}$ After the Khmer Rouge regime, this man was gradually removed from his traditional responsibility by the province's director of Culture, but for all the inhabitants of the area he remains the legitimate servant of Khleang Muang.

${ }^{40}$ These trees from the virgin forest impart their potency to Buddhist statuary which is a bearer of parami.
} 
This mythical-historical geography of potent places mapped out on the ground extends beyond the traditional local territory (the sruk, the area lived in, a few dozen square kilometres) to attach itself, via legends, to the great post-Ankgorean royal capital of Lovek (to the southeast of Lake Tonle Sap). This is the case, for example, of Bakan monastery, another place whose potency is derived from a laterite tower and a huge, majestic banyan tree that has grown on its side, with a particular cult attached to it. This famous banyan is a travelling tree linking PMB, Bakan and the former sixteenth century capital, Lovek. According to one of the versions told to me by a lay ritual specialist, Mr Nuen, at the time of the war with the Siamese, King Ang Chan planted a banyan seed on the esplanade where the Khmer soldiers were encamped (which subsequently became the PMB monastery). As I have already recounted, he asked for a sign that the Siamese would be defeated. He obtained this sign: after seven days, three leaves sprouted from the banyan seed, and he defeated his enemies. After the victory, Ang Chan took this shoot to his new capital, Lovek, where he replanted it before leaving Lovek for Tuol Basan. ${ }^{41}$ He left behind the banyan that was now too big to be transplanted. But the tree felt 'homesick for its native territory', so, during the rainy season, it uprooted itself and floated as far as PMB. When they saw it, the villagers tried, unsuccessfully, to pull it out of the water. When it arrived in Bakan, the people took seven [ritual] cotton strings and incense and asked the banyan to come out of the water. It accepted and established itself permanently on the ruined tower. According to the ritual specialists who told me one version of the story, the name of Bakan comes from pān $k \bar{a} r$ which refers to something that has been obtained, in this case, the banyan. ${ }^{42}$

\section{Conclusion}

In this detailed ethnography of a network of places perceived as potent by the neighbouring villagers and visitors from all social backgrounds, coming from all around Cambodia, I have aimed to render the complexity of the constitutive elements of potency.

As I have pointed out in the Introduction to this special issue, potent places in Cambodia and more broadly in Southeast Asia are sites overloaded, filled and saturated by meanings,

${ }^{41}$ The royal post-Angkorean site of Santhor-Basan is $20 \mathrm{~km}$ north-west of Phnom Penh, on a former course of the Mekong.

${ }^{42}$ Legends of travelling trees can also be found in Burma, according to Bénédicte Brac de la Perrière (personal communication, 2012). 
symbols, practices, and narratives rather than separated from ordinary, profane spaces - as sacred places are usually analysed. In the case study presented here as well, many components can be found which are all related to the epic of an ancient Khmer king and his army general (embodied by statues, local legends more or less inspired by the royal chronicles, ruins of old towers, precious items supposed to be hidden in them ...), Buddhism (represented by abbots, lay ritual specialists, statues of the Buddha, monasteries...) and land guardian spirits as well as, to a lesser extent, other spirits (brāy, grū of Khleang Muang) merged into their natural environment (termite mounds, big old trees, animals...). All these elements are organised together in a complex but coherent system where Buddhism is shaped by Khmer villagers into the framework of land guardian spirit cults, in a way comparable to that described by Holt (2009) in Laos - although, according to Holt and other sources (Archaimbault 1973 [1964]) there is not a mediating concept such as paramī between Buddhism and phi spirits in the latter country. Also, potent places are the way in which Khmer people appropriate the distant institution of the monarchy.

All the potent places described here are perceived as producing, receiving (through rituals and offerings) and transmitting an energy (in their capacity of interacting with human beings in a positive or negative manner). At first glance, this impersonal, moving and fluctuating energy relating objects, institutions, places and human beings is recognisable in the 'notion of animacy in the classic animistic sense of anthropomorphic consciousness, subjectivity and agency' (Århem 2016, 22) that has been documented in the Southeast Asian cosmologies (although studied to a greater extent in Austronesian societies than in Austroasiatic ones). Inside this broad, animistic notion of energy, the Khmer people introduce a specification reflecting the importance of the institutions both of monarchy and Buddhism. The potency and subsequent power of the kings stemming from their commitment to the protection of the Sangha and their ability to rule following the Dharma is known in Cambodia and Thailand as pāramī. As I have shown in this case study, places associated with the monarchy and Buddhism act as sources of paramī; a fact which has been observed through various configurations but rather obliquely by other authors for Thailand (Johnson 2011; Ünaldi 2014) and Cambodia (Bertrand 2001). Although land guardian spirits merged in their specifically shaped natural environment also produce similar energy, they have a lower ranking vis-à-vis Buddhist deities and Buddhism as a whole and are therefore attributed an energy with a slightly different name, paramī. The hierarchical delineation of what is called 'Buddhism' and 'Brahmanism' - the latter name used to label spirit cults — is a major aspect of the evolving 
configuration of the Buddhist field in Cambodia (Davis 2016; Guillou 2017 ${ }^{43}$ ). What the example of potent places clearly shows is that Khmer villagers are developing cultural strategies to maintain the two fields of practices as interconnected despite mounting pressure from the orthodox group inside the Sangha to expel spirit cults from the religious field (Guillou 2017).

Finally, I would like to return to the broad conception of cosmic energy formulated by Århem $(2016,22)$ in his discussion of animism in Southeast Asia. The 'impersonal vital force or creative energy animating the entire cosmos' can to some extent be applied to the animistic idea of potency in the Khmer Weltanshauung which considers the Khmer society-as the example of potent places among others suggest — to be regulated by the circulation of fluids and forces. This 'animistic' energy is a 'horizontal' one while the potency associated with the monarchy and royalty is centralised and vertical in the sense that it is produced by the highest institutions of the kingdom and is situated at a great distance — - both social and geographicalfrom the villages. How do these two conceptions of energy work together? It is not easy to ascertain how the ordinary Khmer people have been aware, in history, of the existence of their king, his regional representatives and the feeling of being subjects of a Khmer kingdom, except, maybe, during the numerous wars with the neighbouring kingdoms.

To suggest a path towards an answer to this question, I will draw on McDaniel's (2002) interpretation of the localisation process of sāsana in sixteenth century Lanna kingdom (northern Thailand). ${ }^{44}$ The Buddhist historical chronicle that McDaniel analyses (among other manuscripts and their interpretations) claims that the Buddha Himself went to Haripuñjaya and hid a relic which, discovered 1500 years later, made Lanna the greatest Buddhist kingdom, directly connected to the Buddha through linear chronology and forming a connection with the sāsana while in turn defining it as a distinct regional expression of that sāsana vis-à-vis other regional dynastic polities. This construction of a 'spatial authenticity through local possession of relics' (180) is on many points similar to the process by which the Khmer villagers appropriate the history of the monarchy through the traces left by the royalty. By anchoring the royal presence in the villages' land, by associating it with land guardian spirits-localising

${ }^{43}$ Davis (2016) focuses on the 'domestication' of the wild forces - particularly those related to deathby the monks and other buddhist ritual specialists while Guillou (2017) analyses the role played by the delineation of two fields of practices labelled as 'buddhist' and 'brahmanist' in the reconfiguration of religious practices in post-communist Cambodia.

${ }^{44}$ See also de Mersan (2012) for a similar process in Arakan (Myanmar). 
forces par excellence - the Khmer peasants recreate for their own use a small part of the monarchical centre.

\section{Acknowledgements}

This research was funded by the French CNRS through the Centre of Southeast Asia Studies (CASE), Paris. I am grateful to Phuong Sakona, Minister of Culture and Fine Arts of Cambodia whose comments during a seminar in Phnom Penh enabled me to make a more accurate analysis of $p \bar{a} r a m \bar{\imath}$. This work has continually benefited from discussions with Ang Choulean. I also wish to thank Bénédicte Brac de la Perrière and the two anonymous reviewers for their useful comments on earlier versions of this article. Justin McDaniel and Erick White kindly made me aware of recent scholarship on pāramī in Thailand.

\section{References}

Aen் Sut. 2000. Ekasār Mahāburas Khmaer, Volume 2. Phnom Penh: Angkor Thom (in Khmer).

Allerton, Catherine. 2009. "Introduction: Spiritual Landscapes of Southeast Asia." Anthropological Forum 19 (3): 235-251.

Ang, Choulean. 1986. Les Êtres Surnaturels dans la Religion Populaire Khmère. Paris : CEDORECK.

Ang, Choulean. 1995. « Le sol et l'ancêtre : L'amorphe et l'anthropomorphe. » Journal Asiatique CCLXXXIII (1): 213-238.

Archaimbault, Charles. 1973 [1964], « Structures religieuses au Laos » in Structures religieuses lao (rites et mythes). Vientiane :Vithagna.

Bertrand, Didier. 2000. «Une pratique mediumnique de possession dans le Cambodge contemporain ». In La politique des esprits, edited by Denise Aigle, Bénédicte Brac de la Perrière and Jean-Pierre Chaumeil, 125-147. Paris: Société d'Ethnologie. 
Bertrand, Didier. 2001. "The Names and Identities of the 'Boramey' Spirits Possessing Cambodian Mediums". Asian Folklore Studies 60 (1): 31-47.

Bizot, François. 1994. «La consécration des statues et le culte des morts.» In Recherches nouvelles sur le Cambodge, edited by François Bizot, 114-116. Paris: Publications de l'EFEO.

Bovensiepen, Judith. 2009. "Spiritual Landscapes of Life and Death in the Central Highlands of East Timor." Anthropological Forum $19 \quad$ (3): 323-338. doi:10.1080/00664670903278437

Chandler. David P. 1972. « Royally sponsored human sacrifices in nineteen-century Cambodia: the cult of neak ta me sar (Mahisasuramardini) at Ba Phnom" The Journal of the Siam Society 62 (2): 209-222.

Davis, Erik W. 2016. Death Power. Buddhism's Ritual Imagination in Cambodia. New York: Columbia University Press.

Din Dīṇā. "Brāḥ Bhūmi”. KhmeRenaissance, Yosothor for Khmer Culture (in Khmer) http://yosothor.org/publications/khmerenaissance/content-header/chapter-two/chaptertwo-copy/preah-phum.html

Forest, Alain. 1992. Le culte des génies protecteurs au Cambodge: Analyse et traduction d'un corpus de textes sur les neak ta. Paris: L'Harmattan.

Formoso, Bernard. 1998. "Bad Death and Malevolent spirits among the Tai Peoples" Anthropos 93: 3-17.

Guillou, Anne Yvonne. 2013. "The living archaeology of a painful heritage: the first and second life of the Khmer Rouge mass graves." In "Archaeologising” Angkor? Heritage between Local Social Practice and Global Virtual Reality, edited by Michael Falser and Monica Juneja, 263-274. Heidelberg and New York: Springer.

Guillou, Anne Yvonne. 2014. "From bones-as-evidence to tutelary spirits: The status of bodies in the aftermath of the Khmer Rouge genocide." In Human remains and mass 
violence: methodological approaches, edited by Elisabeth Anstett-Gessat and Jean-Marc Dreyfus, 146-160. Manchester: Manchester University Press.

Guillou, Anne Yvonne. 2016. «Le 'maître de la terre'. Les cultes rendus au cénotaphe de Pol Pot (Nord du Cambodge) » In La mort du bourreau. Réflexions interdisciplinaires sur le cadavre des criminels de masse, edited by Sévane Garibian, 65-86. Paris: Petra.

Guillou, Anne Yvonne. 2017. «The (re)configuration of the Buddhist field in postcommunist Cambodia". In The Appropriation of Religion in Southeast Asia and Beyond, edited by Michel Picard 67-94. New York: Palgrave Macmillan.

Holt, John Clifford. 2009. Spirits of the place. Buddhism and Lao Religious Culture. Honolulu: University of Hawai'i Press.

Johnson, Andrew. 2011. "Re-centreing the city: spirits, local wisdom, and urban design at the Three Kings Monument of Chiang Mai” Journal of Southeast Asian Studies 42 (3): 511531.

Jory, Patrick. 2002. "The Vessantara Jataka, Barami, and the Bodhisatta-kings: The Origin and Spread of a Thai Concept of Power" Crossroads: An Interdisciplinary Journal of Southeast Asian Studies 16 (2): 36-78 Stable URL: http://www.jstor.org/stable/40860799

Khin, Sok. 1988. Chroniques royales du Cambodge : Vol. II. Paris : Ecole Française d'Extrême-Orient.

Leclère, Adhémard. 1910. « Le Sdech Kan » Bulletin de la Société des Études Indochinoises $59: 17-55$.

Lewitz, Saveros. 1969. " Note sur la translittération du cambodgien » Bulletin de l'Ecole Française d'Extrême-Orient LV : 163-169.

Locard, Henri. 1996. Le "Petit livre rouge » de Pol Pot ou les paroles de l'Angkar. Paris : L'Harmattan. 
Martin, Marie Alexandrine. 1971. Introduction à l'ethnobotanique du Cambodge. Paris: CNRS/CEDRASEMI.

de Mersan, Alexandra. 2012, «The 'Land of the Great Image' and the Test of Time. The Making of a Buddha Image in Arakan (Burma/Myanmar)». In The Spirit of Things: Materiality in the Age of Religious Diversity in Southeast Asia, edited by Julius Bautista, 95110. Ithaca: Cornell Southeast Asia Program Publications.

Mus, Paul. 1933. "Cultes indiens et indigènes au Champa », Bulletin de l'Ecole Française d'Extrême-Orient XXXIII (1) : 367-410. Engl transl. Mus, Paul. 1975. India Seen from the East : Indian and Indigenous Cults in Champa. Monash Papers on Southeast Asia no3, Melbourne: Monash University Centre of Southeast Asian Studies.

McDaniel, Justin. 2002. "Transformative History. Nihon Ryōiki and Jinakālamālīpakaraṇam”, Journal of the International Association of Buddhist Studies 25(1-2): 151-207.

Norén-Nilsson, Astrid. 2013. "Performance as (re)-incarnation : The Sdech Kân Narrative » Journal of Southeast Asian Studies 44 (1): 4-23.

Persons, Larry Scott. 2008. "The anatomy of Thai face" Manusya: Journal of Humanities 11(1): 53-75.

Porée-Maspero, Evelyne. 1962-1964-1969. Étude sur les rites agraires des Cambodgiens. Paris/La Haye : Mouton/EPHE, 3 vol.

Sirindhorn, HRH Princess Maha Chakri. 2006. "Pāramī. A Buddhist concept in the Thai context”. In Buddhist Legacies in Mainland Southeast Asia. Mentalities, Interpretations and Practices, edited by François Lagirarde and Paritta Chalermpow Koanantakool, 19-31. Paris and Bangkok : Sirindhorn Anthropology Center and EFEO.

Thompson, Ashley. 2008. "Performative Realities : Nobody’s Possession.” In Songs on the Edge of the Forest: Narrative and Problems of Meaning in the Work of David Chandler, 
edited by Anne Ruth Hansen and Judy Ledgerwood, 93-120. Ithaca, NY: Asian Studies Press, Cornell University.

Ünaldi, Serhat. 2014. "Working Towards the Monarchy and its Discontents: Anti-royal Graffiti in Downtown Bangkok”. Journal of Contemporary Asia, 44 (3): 377-403.

DOI: $10.1080 / 00472336.2013 .842260$

Work, Courtney. 2017. "The Persistent Presence of Cambodian Spirits: Contemporary Knowledge Production in Cambodia”, In Routledge Handbook of Cambodia, edited by Simon Springer and Katherine Brickel, 389-398. Oxon, OX: Routledge.

Yamada, Teri Shaffer. 2004. "The Spirit Cult of Khleang Moeung in Long Beach, California" In History, Buddhism, and New Religious Movements in Cambodia, edited by John Marston and Elizabeth Guthrie, 213- 225. Honolulu : University of Hawaii Press.

\section{List of images}

Image 1 - Khleang Muang's shrine. Pursat. 2008. Author's picture

Image 2 - Potent places associated with Khleang Muang's legend

Image 3 - Shrine of Brāh jī. Ming San asks Grandfather Chi's help in a land grabing case. Pursat. 2007. Author's picture.

Image 4 - The potent old tower in PMB monastery. Pursat. 2008. Author's picture.

Image 5 -Incorrectly moulded cement statues kept near the old tower, PMB monastery. Pursat. 2008. Author's picture. 